\title{
Sedimentary response to tectonic uplift of the Dukla basin margin recorded at Skrzydlna - the Menilite Beds (Oligocene), Outer Carpathians, S Poland
}

\author{
Aneta Siemińska, Krzysztof Starzec, Paweł Godlewski, Marek Wendorff \\ AGH University of Science and Technology, Faculty of Geology, Geophysics and Environmental Protection; \\ al. A. Mickiewicza 30, 30-059 Krakow, Poland; \\ e-mail:anet.sieminska@gmail.com,kstarzec@agh.edu.pl,godlewski@agh.edu.pl,wendorff@agh.edu.pl
}

(C) 2018 Authors. This is an open access publication, which can be used, distributed and reproduced in any medium according to the Creative Commons CC-BY 4.0 License requiring that the original work has been properly cited.

Received: 24 January 2018; accepted: 16 April 2018

\begin{abstract}
The Menilite Beds (Oligocene of Polish Flysch Carpathians) at Skrzydlna crops out in a structurally complex zone of the Fore-Magura Unit, which is tectonically overridden by Magura Nappe thrust form the S. The exposed sedimentary suite, representing the Dukla Basin, consists of fine-grained, well organised strata deposited in a low-energy, deep marine basin, which are abruptly overlain by poorly organised, coarse sandy conglomerate that forms a Mass Transport Deposit (MTD) complex. The MTD contains large boulders of extrabasinal rocks, massive sandstone beds with intrabasinal mudstone clasts, and slump sheets of sandstones. Above rests a fining-upwards sequence of sandstone beds interlayered with mudstones. The fine-grained facies reappear above to terminate the exposed succession. Erosional contacts and rapid facies changes, both vertical and lateral, are characteristic for the MTD unit. The sandstone-mudstone unit above contains laterally migrating erosional channels filled with massive sandy conglomerate in the lower part. Turbidites of varying density and completeness of internal structures that occur above are accompanied by an association of mixed facies including large-scale dune cross-bedding.

Mineralogically, the sandstones are quartz arenites, sub-lithic arenites and wackes. Calcarenite grains - bioclasts, micrite and marl occur in substantial proportions only in the uppermost part of the succession. The point-counting data plotted on Qm-F-Lt diagram are clustered within the recycled fields: quartzose and transitional. Mineralogical maturity of the sandstones has the tendency to decrease from the sub-MTD strata upwards via the MTD unit to the lower part of the sandstone-mudstone complex; then it increases to the youngest sandstone beds with carbonate grains. These tendencies, associated with sedimentary features of the succession, reflect rapid uplift, emergence and progressive erosion of the terrigenous detritus source area, followed by tectonic stabilisation reflected by the appearance of the "carbonate factory".
\end{abstract}

Keywords: tectonics and sedimentation, Mass Transport Deposit (MTD), turbidites, Menilite Beds, Carpathians

\section{INTRODUCTION}

Abrupt extreme facies changes in stratigraphic successions of marine sedimentary strata usually reflect onset of quite rapid tectonic deformations within the basin or at its margins (Postma
\& Kleverlaan 2018). This is the reason why studies of such changes have important implications for interpretation of tectonic processes. Furthermore, there where coarse clastic deposits appear invaluable information on the composition of the source area can be gathered. The Oligocene 
deep marine succession at Skrzydlna (Burtan 1974, 1978, Polak 2000), which represents one of such cases, is located in the Outer (Flysch) Carpathians in the tectonic zone extending in front of the Magura Nappe, which in the opinion of the present authors should be equated with western part of the Dukla sedimentary basin (see the next chapter) (Fig. 1). The succession begins with a fine-grained, very well organised suite deposited in low-energy environment, which is suddenly overlain by poorly organised, extremely coarse conglomerate complex succeeded by a sandstone and mudstone sequence, above which well organised fine-grained facies appear again. The conglomerate complex forms an olistostrome sequence (Wendorff et al. 2015), which in accordance with the currently prevailing terminology will be called Mass Transport Deposit (MTD) complex further in the text.

Considering the above relations, the aim of this paper is threefold. It intends to (1) present variations of facies and sedimentary features, and consider the mechanisms of sediment emplacement, because these are controlled by the basin palaeotopography, (2) analyse mineral composition of the detrital components as the reflection of their provenance, and (3) discuss these aspects from the viewpoint of tectonic evolution of the area.

\section{GEOLOGICAL SETTING}

The studied area is located in the middle part of the Polish Outer Carpathians (Fig. 1). In general, the Outer Carpathians are regarded as an ancient accretionary wedge (e.g. Oszczypko 2006), with the present structure consisting of several thrust sheets traditionally referred to as nappes or tectonic units. From the south to north these are: the Magura Unit, Fore-Magura Group of Units including the Dukla Unit, Silesian, Sub-Silesian, and Skole Units (Książkiewicz 1977). It is regarded that the rock succession in each of the tectonic units is related to a separate sedimentary basin, therefore they reveal different lithostratigraphic compositions (Koszarski et al. 1974, Książkiewicz 1977, Ślączka et al. 2006). The successions evolved during the Oligocene to Miocene folding and thrusting that formed a stack of tectonic units thrust over each other with prevalent northern direction of movement.

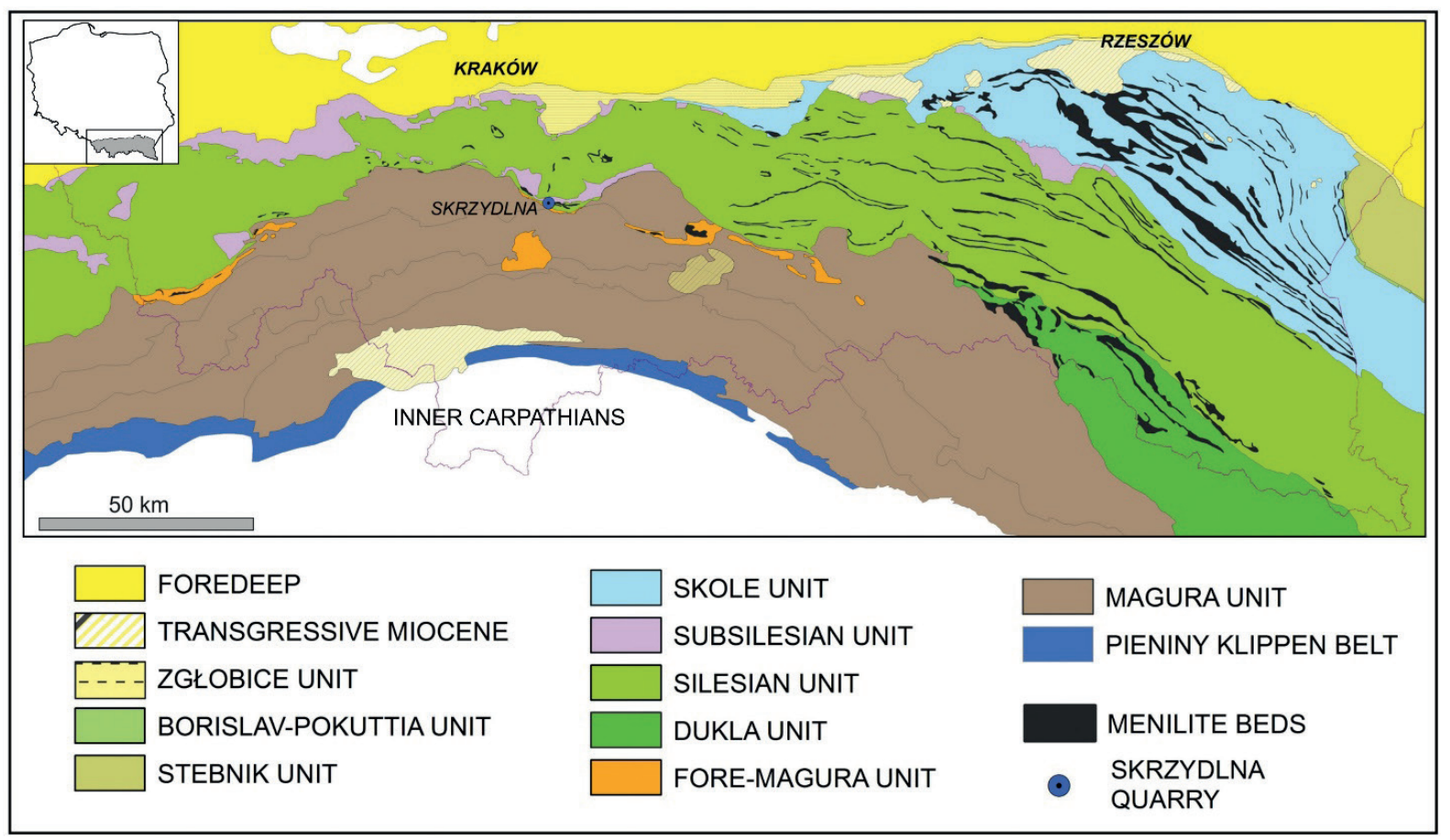

Fig. 1. Schematic structural map of the Polish part of the Carpathians showing the main tectonic units/nappes (after Żytko et al. 1989), occurrences of the Menilite Formation and the location of Skrzydlna 
The studied Oligocene succession is exposed in a mining quarry near the local road between Skrzydlna and Kasina Mała (Fig. 2). It represents the Menilite Beds that together with the overlying them sandstone succession of the Krosno Beds occur in a narrow zone of steeply dipping strata. This zone is situated in a structurally complex area and represents one of the Fore-Magura thrust units (Fig. 3), which in the broadest sense can be correlated with the Dukla Unit (Kotarba et al. 2017).

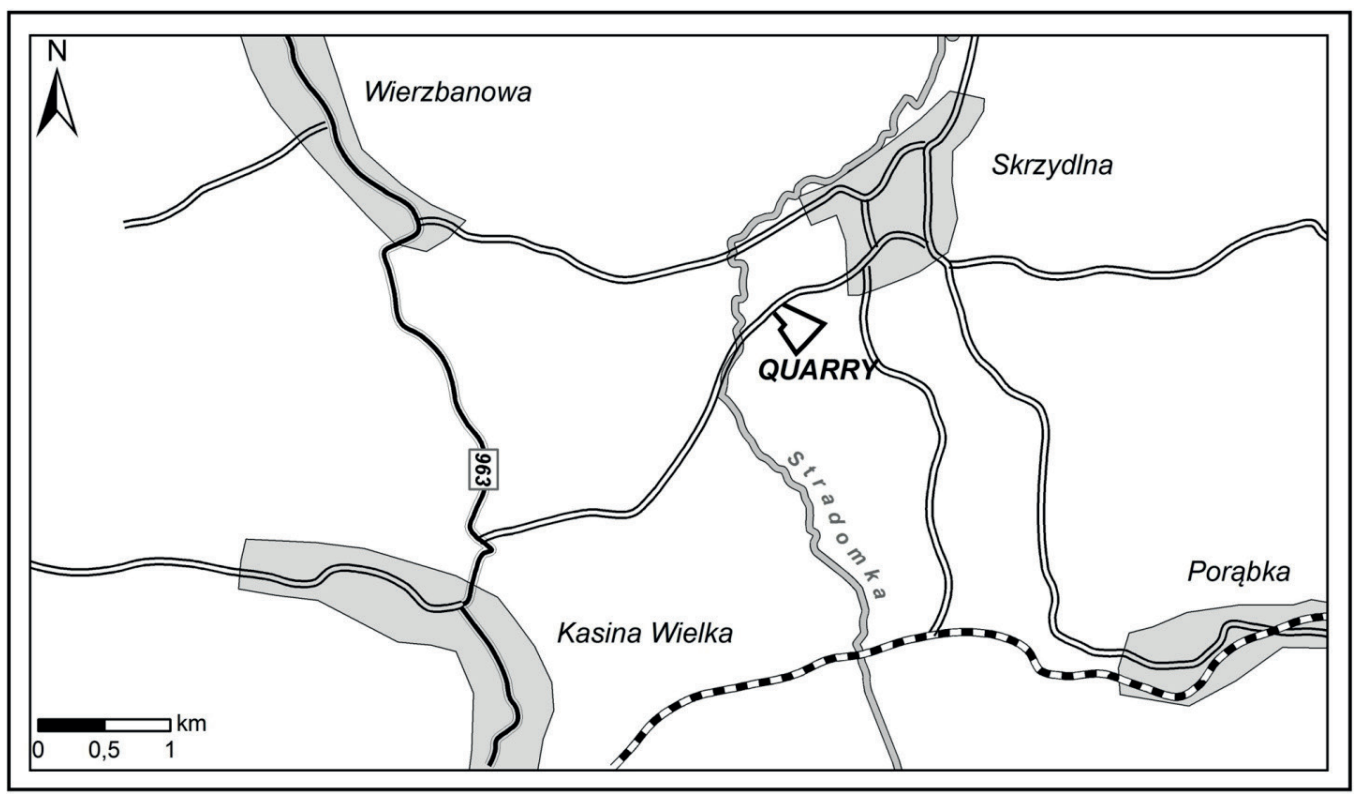

Fig. 2. Schematic locality map of the Skrzydlna quarry (GPS coordinates: $\left.49^{\circ} 44^{\prime} 55 \mathrm{~N}, 20^{\circ} 9^{\prime} 58 \mathrm{E}\right)$

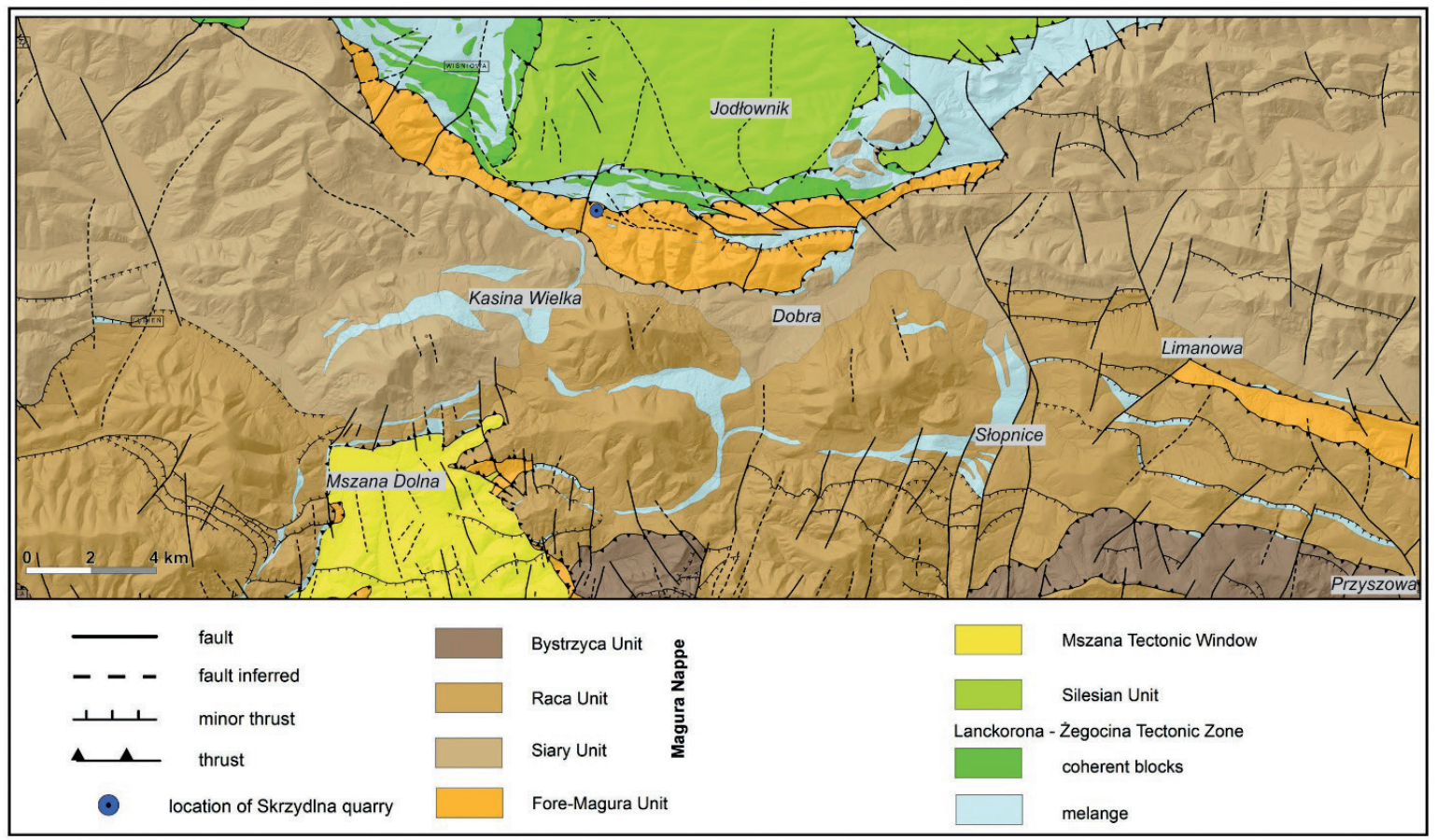

Fig. 3. Regional tectonic sketch showing structural relations in the Skrzydlna region: the Magura Nappe thrust northward onto the Fore-Magura Unit to the north of which extends the Lanckorona-Żegocina Tectonic Zone with tectonic mélange (Sieminska et al. 2017a, modified) 
In the western part of the Carpathians this Unit crops out only in tectonic windows or semi-windows, like in the area of Skrzydlna, where it strikes along NW - SE direction right at the front of the Magura Nappe. The latter forms here a tectonic bay called the "Skrzydlna Tectonic Bay". To the SE, the Dukla Unit is hidden under the overthrust of the Magura Nappe, but farther to the SE its extension appears in several elongated tectonic windows within the Nappe.

In the past, however, the geological setting of the area has been variably interpreted. In the Mszana Dolna Sheet of the Detailed Geological Map of Poland, Burtan (1974) included this area in the Silesian Unit. Similar interpretation was presented by Konon (1997) and Cieszkowski et al. (2012). However, Polak (1999) suggested that because of occurrence of sandstones resembling the Cergowa lithotype, this area might represent the Fore-Magura Unit (Dukla or Grybów Units). In this vein, the rocks present in this area are regarded as a direct, western extension of the Dukla Unit, which is fully exposed farther to the East (Ślączka \& Kamiński 1998, Cieszkowski et al. 2009, Jankowski et al. 2012, Kotarba et al. 2017).

The structural development of the Dukla Unit at Skrzydlna is related to the Lanckorona-Żegocina Zone of tectonic mélange that borders the Unit from the north. This zone resulted from either diapiric-type migration of less competent formations along a strike-slip fault (Golonka et al. 2011) or multistage deformation involving out-ofsequence thrusting, strike-slip and normal faulting (Jugowiec-Nazarkiewicz 2007, Jankowski et al. 2012). Anyway, after its emplacement as a thrust sheet, the northern part of the Dukla Unit in the Skrzydlna area was influenced by intense deformation along the Lanckorona-Żegocina Tectonic Zone during the compressional phase of evolution of the Carpathian accretionary wedge. This origin determined the orientation of the tectonic components of the area in question, as well as the structure of steeply dipping beds, observed in the Skrzydlna quarry.

The lithostratigraphic succession of the Dukla Unit exposed in tectonic windows within the marginal part of the Magura Unit comprises sediments of the Senonian to Oligocene age (Sikora
1970, Oszczypko-Clowes \& Ślączka 2006). The Senonian deposits are represented by the Jaworzynka Beds. These are succeeded by the Lower to Upper Eocene green and grey shales with intercalations of thin sandstones (the Hieroglyphic Beds), which are overlain by the Globigerina Marls at the transition between the Eocene and Oligocene. The Early Oligocene deposits are represented by of the Menilite Beds that are locally named Sub-Grybów and Grybów beds. Within them, a lithosome of the Cergowa Sandstones is distinguished (Cieszkowski 1992). The uppermost part of the succession is composed of grey sandstones and shales of the Krosno Beds. In the Skrzydlna area, the Dukla - Fore-Magura lithostratigraphic succession is composed of about $300 \mathrm{~m}$ thick series of the Menilite Beds, which includes up to $200 \mathrm{~m}$ of the Cergowa Sandstones and is succeeded by over $1000 \mathrm{~m}$ thick complex of the Krosno Beds. The Hieroglyphic Beds that underlie this suite are only locally preserved.

The Oligocene (Olszewska 1985, Švábenická et al. 2007) succession of the Menilite Beds is typified by a distinctive organic-rich lithofacies that is widespread in the Carpathians (Kotlarczyk et al. 2006, Puglisi et al. 2006, Fig. 1). It is composed mainly of dark brown and black shales, chert and siliceous marls with minor intercalation of sandstones, which are commonly considered as deposited in the generally anoxic basin (Olszewska 1985, Švábenická et al. 2007, Soták, 2010). Thickness of these deposits varies at a regional scale from c. $100 \mathrm{~m}$ in the southern part of their occurrence, up to $550 \mathrm{~m}$ in the northern part (a.o. Jucha \& Kotlarczyk 1961, Haczewski 1989, Kuśmierek 1990, Leszczyński et al. 2008). However, in some areas, especially in the Dukla Tectonic Unit (in the SE part of map shown in Fig. 1), the Menilite Beds contain also thick sandstone bodies that may occasionally comprise half of their total thickness (Ślączka 1971, Ślączka \& Unrug 1976, Pszonka 2015, Pszonka \& Wendorff 2017). A unique value of this unit lies in a relatively high content of organic matter, reaching 20\% (e.g. Curtis et al. 2004) and thus, they represent the most important source rock for hydrocarbons in the entire Carpathian realm. Thick sandstone complexes within and above the Menilite Beds are, 
in turn, significant reservoir rocks (Dziadzio et al. 2006). Because of that, the Polish Carpathians constitute one of the oldest petroleum provinces in the world, where oil exploitation dates back to the middle $19^{\text {th }}$ century (Karnkowski 1999, Selley \& Sonnenberg 2015).

A broad array of lithologies represented by pebbles in the MTD conglomerates at Skrzydlna was noted by the previous authors (Polak 2000, Cieszkowski et al. 2009). They reported limestones and marls, Jurassic and Cretaceous in age, conglomerates, limestones and sandstones derived from the Paleogene strata, rare Devonian limestone clasts, as well as granite, gneisses and metamorphic schists. The same authors interpreted mappable occurrences of the Cretaceous rocks that occur to the south of Skrzydlna as huge olistoliths (olistoplaques).

\section{MATERIALS AND METHODS}

Geological field mapping was conducted on a scale 1:25,000 and the final interpretation involved LiDAR image analysis. Sedimentary features of the strata outcropping in the open pit face at Skrzydlna were measured bed-by-bed. Azimuths of palaeocurrent indicators were taken and 50 samples for qualitative and quantitative (point counting) analysis of mineral composition collected to represent all arenite varieties. Point counting analysis involved identification of rock components at 300 observation points per thin section.

\section{LITHOSTRATIGRAPHY AND SEDIMENTARY FEATURES}

In general, the quarry face exposes dark-coloured menilite shales with a thick interbed of orange-weathering sandstone followed by whitish weathering limestone (Fig. 4). The limestone is overlain by orange in colour MTD complex of sandy conglomerates quickly passing upwards into a fining-upwards (F-U) turbidite sequence. The beds are dipping steeply and occupy stratigraphically normal position dipping to the right in the left-hand part of the quarry face; the dip gradually changes to overturned towards the right-hand part of the outcrop (Fig. 4).

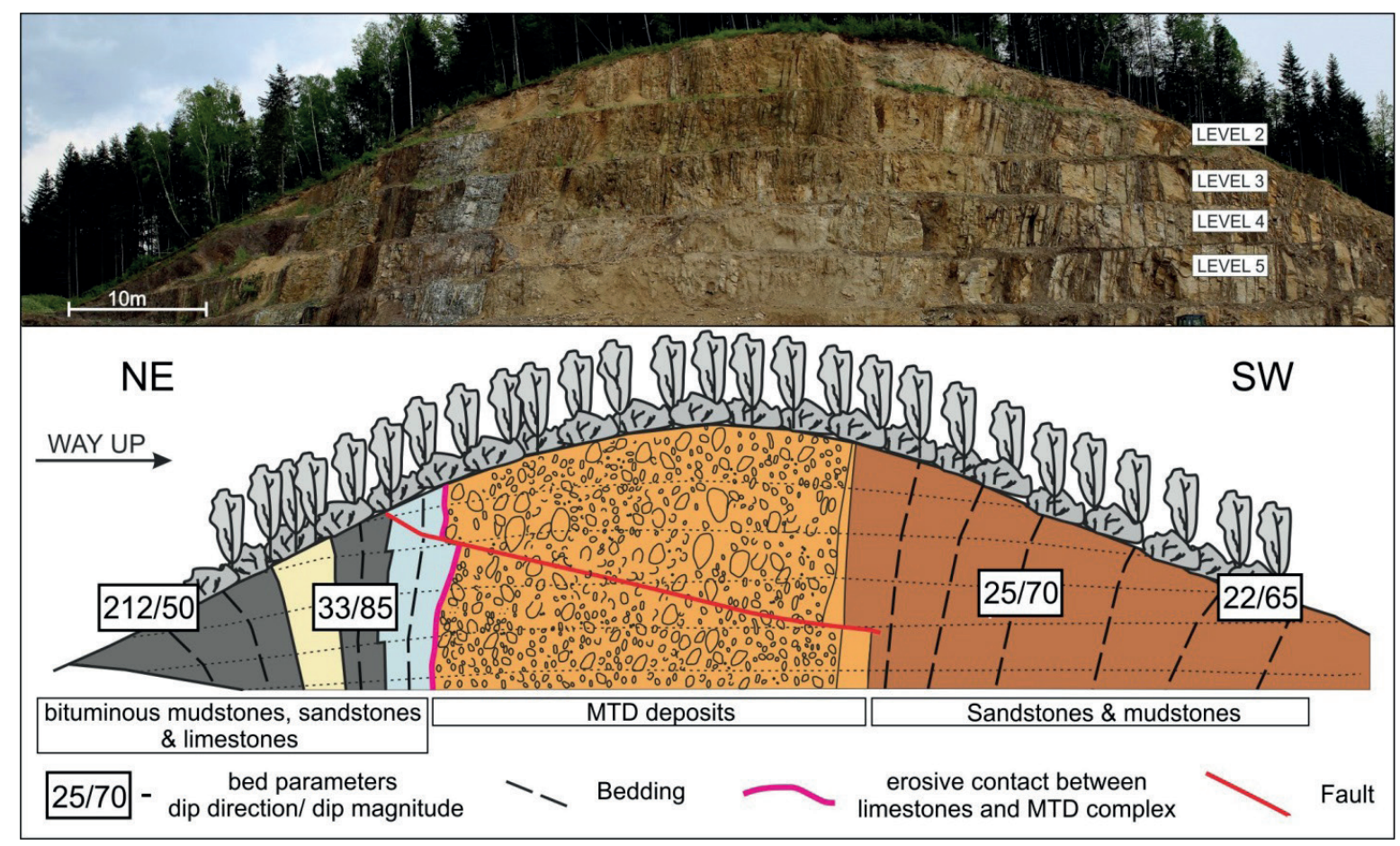

Fig. 4. General view of the Skrzydlna quarry face showing subdivision into the main lithological intervals and gradual changes of bed attitude. Dotted lines denote operational/mining levels 2-5 labelled in the photograph above 
Stratigraphically, the section at Skrzydlna (Fig. 5) begins with the association of lithofacies characteristic for the Menilite Beds. This unit is a $53 \mathrm{~m}$ thick suite of dark, calcareous mudstones with thin intercalations of turbidite sandstones with current ripplemarks (Tc) followed by cherts with siliceous mudstones and subordinate thin sandstone layers. These are overlain by amalgamated thick sandstone beds succeeded by dark mudstones with cherts and up to $12.5 \mathrm{~m}$ thick - series of pelitic limestone with solitary current ripplemarks and rare very thin laminae of terrigenous/quartz sand. The limestone is hard, very dark grey in colour, weathering light grey to whitish and locally silicified; in general, they represent the lithotype of so-called Dynów Marls. Both, the dark mudstones and the limestones are injected by sandstone dykes ranging from $5 \mathrm{~cm}$ to $30 \mathrm{~cm}$ across. The MTD complex above marks tectonically-induced rapid change in conditions of deposition, namely it is erosionally incised in the underlying limestone and consists of $43 \mathrm{~m}$ thick suite of conglomerates with frequent erosional bases, sandstones and very rare thin mudstone beds, which form mud drapes marking breaks in coarse-clastic sedimentation. This is followed by a $70 \mathrm{~m}$ thick irregularly fining-upwards (F-U) heterogeneous sequence of fine- and medium-grained, thick- to thin-bedded sandstone beds and subordinate mudstones, including classic turbidites; these rocks are called sandstone complex further in the text.

The MTD complex base is uneven, grooved and erosionally incised into the underlying limestone complex, with grooves oriented along the NW-SE trend.

The complex consists of five predominant lithofacies:

A - Clast-supported conglomerate constitutes the most coarse-grained facies of the MDT sequence. Lower bed boundaries are usually erosional, bed thickness attains $4 \mathrm{~m}$, maximum clast diameter reaches $80 \mathrm{~cm}$. The components are poorly sorted, the structure is massive, and chaotically distributed and oriented clasts are embedded in sandy matrix.

B - Matrix-supported conglomerate facies is subdivided into two sub-facies based upon the coarsest fraction: $\mathrm{B} 1$ - exceeding $32 \mathrm{~mm}$ in diameter (i.e. very coarse pebbles and boulders) and B2 - with pebbles very fine to coarse, less than $32 \mathrm{~mm}$ across. Both subfacies contain sandy matrix, with clay matrix absent. Maximum clast diameter reaches $100 \mathrm{~cm}$, maximum bed thickness varies from $150 \mathrm{~cm}$ to $350 \mathrm{~cm}$, beds are either massive or normally graded. Normal grading occurs as two varieties: distribution grading or coarsetail grading. Large clasts are either chaotically distributed or aligned parallel to the bedding, sometimes projecting above the upper bed boundary. Lower boundaries are sharp erosional or gradational.

$\mathrm{C}$ - The facies of conglomerate passing upwards into sandstone is represented by usually medium- to fine-grained conglomerates that occur in the lower parts of beds and pass upwards to massive or normally-graded sandstone intervals.

D - Sandstones are medium- and fine-grained, sometimes containing fine pebbles and granules in the lowermost part of bed. Structurally are massive, sometimes containing trains of mudstone rip-up clasts oriented parallel to bedding. Normally graded varieties are vertically transitional to ripple cross-lamination intervals covering bed tops.

E - Mudstone beds form only a few horizons 5-15 cm thick, sometimes enriched in sand grains in the lower part. Lower and upper boundaries are sharp, with tops locally erosionally dissected by the overlying conglomerate. Usually dark grey throughout, but sometimes transitional upwards into black, Menilite-beds lithotype.

F - Sandstone graded into mudstone: formed by only two thick beds of coarse-grained sandstone normally graded to fine-grained, parallel-laminated arenite enriched in coalified plant detritus, which evolves upwards into massive mudstone top.

$\mathrm{G}$ - Sedimentary breccia forms one bed $50 \mathrm{~cm}$ thick, laterally pinching out over a distance of a few metres and composed of angular mudstone and sandstone clasts embedded in sandy matrix. 


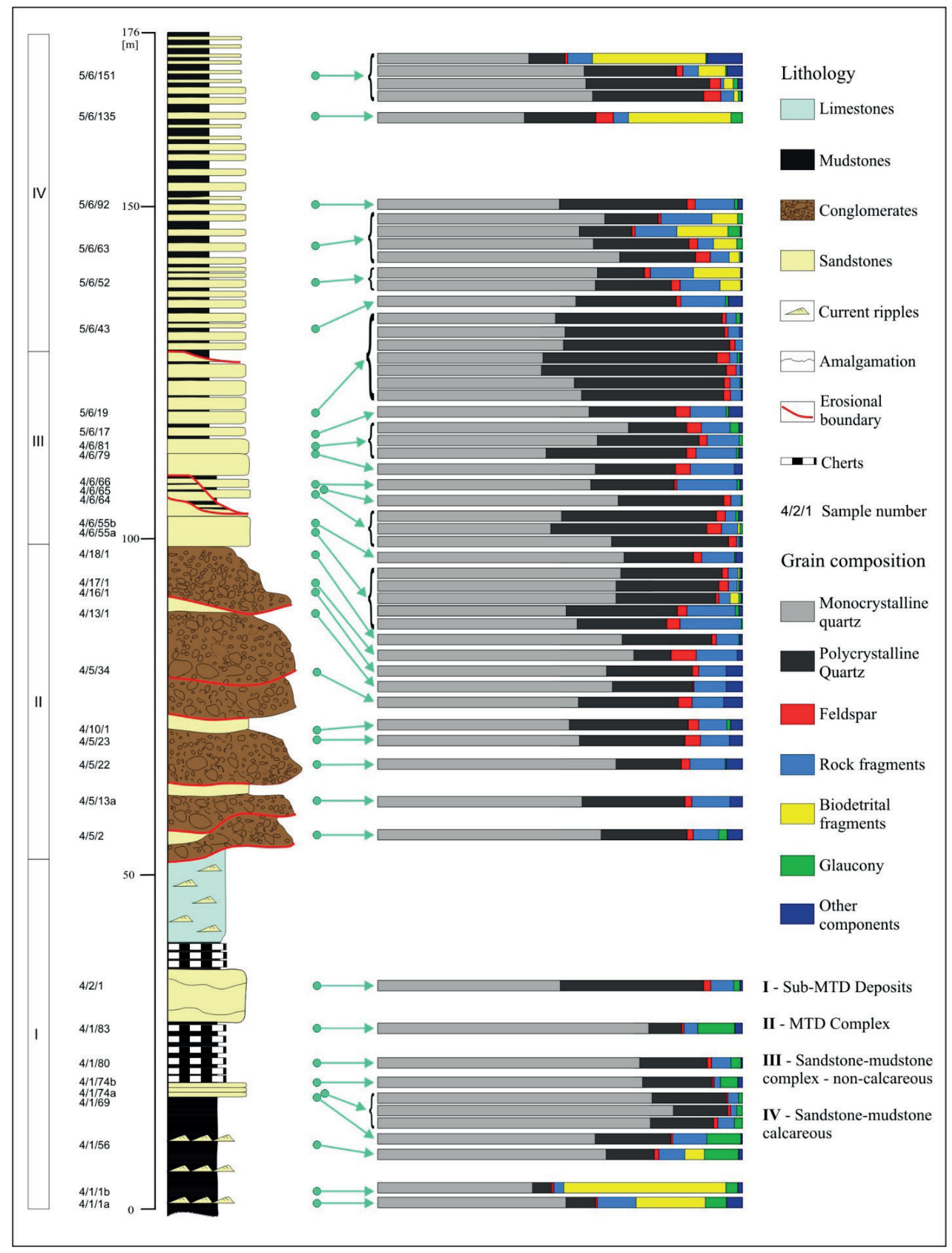

Fig. 5. Lithological column of the succession at Skrzydlna (Siemińska et al. 2017b, modified), sampling points and quantitative results of mineral composition analysis of framework grains shown as bars. Intervals I-IV indicate facies complexes discussed in text 
Conglomerates of facies A occur most commonly together with facies $\mathrm{B}$ and associations of these two fill erosional channels incised into finer-grained strata - C, D and E. There are seven such channels in the whole MTD complex, with the largest channel $3.3 \mathrm{~m}$ deep and at least $46 \mathrm{~m}$ wide (extending beyond the outcrop margin) (Fig. 6). Lateral transitions of facies $\mathrm{A}$ and $\mathrm{B}$ are frequent and reflected by change in the sand matrix proportion varying between clast- and matrix-supported, which reflects considerable lateral variations in hydrodynamic characteristics of the flows. A few hybrid beds (Haughton et al. 2009) composed of massive sandstone interval overlain by debris of black mudstone derived from erosion of the underlying reduced Menilite Beds and embedded in sandy matrix occur locally in the MTD complex.

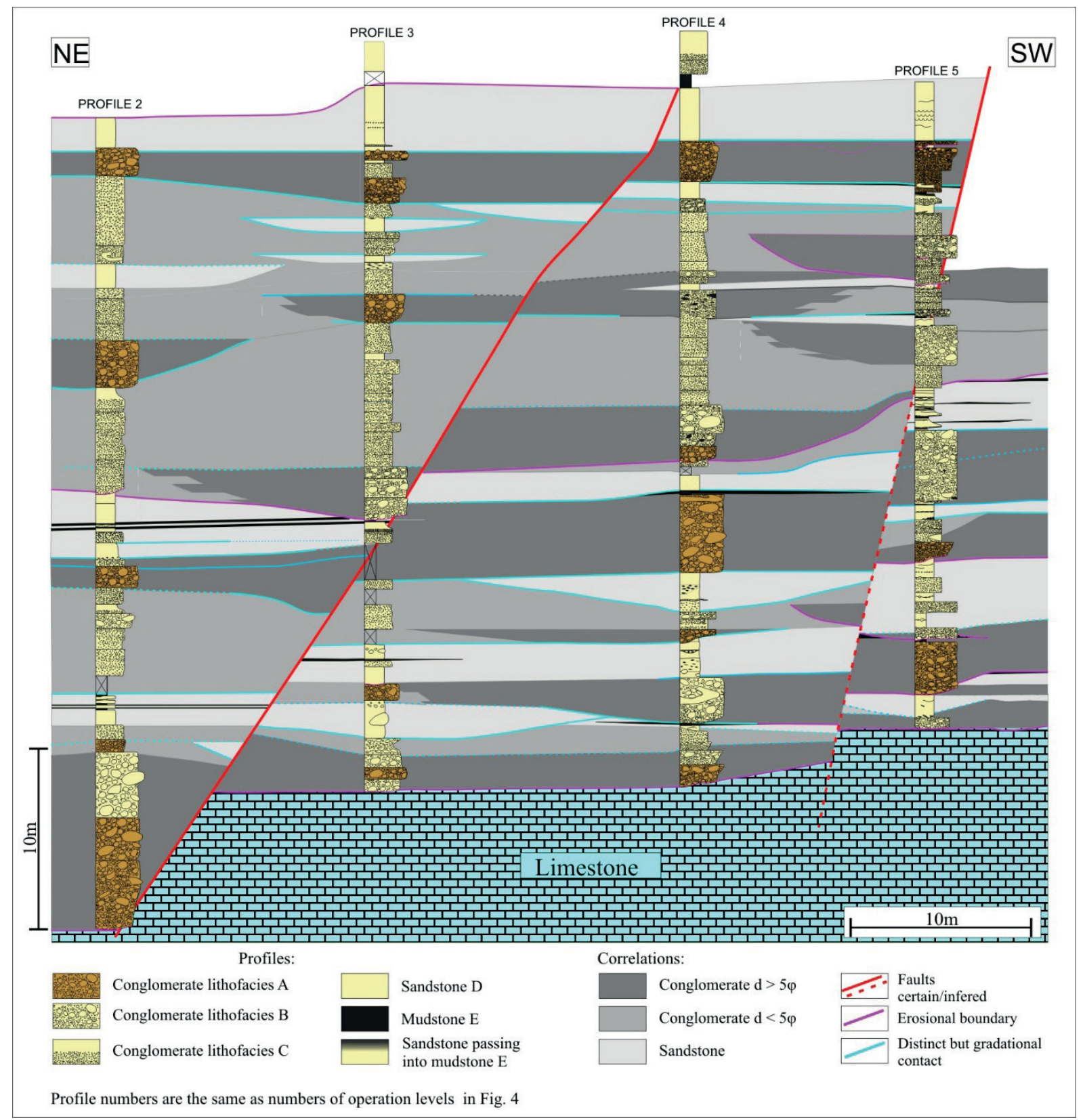

Fig. 6. MTD complex: correlation of individual measured sections distributed at the face of the quarry at exploitation levels 2-5 (shown in Figure 4). Note: frequent erosional contacts and rapid facies variations, both vertical and lateral (Sieminska et al. 2017a, modified) 
The upper boundary of the MTD complex is marked by a $1 \mathrm{~m}$ thick layer of black mudstone, which reflects a considerable break in coarse clastic sediment supply. It is highly possible that the break was caused by a period of tectonic quiescence. Above, there is a fining upwards mixed sequence of sandstones, mudstones and subordinate fine conglomerate layers. Four erosional channels, ranging from $2 \mathrm{~m}$ to $15 \mathrm{~m}$ in depth characterise its lower part and account for considerable lateral changes of facies. They are filled with thick layers of sandstones, fine-grained conglomerates and mudstones. Lateral migration of the channels towards the SW is accompanied by a gradual decrease in grain size of the infilling sediment. Very thick amalgamated sandstone beds appear above. Overlying them is a single channel, which marks a boundary between the non-calcareous part of the succession below and the overlying it sequence of quartz arenites containing admixtures of carbonate grains. This interval contains layers of large- and small-scale cross-bedded arenites (with current ripples and dunes) interbedded with parallel-laminated sandstones. The uppermost part of the succession is dominated by current-ripple laminated sandstones passing into mudstones, and layers of mudstone. These are interlayered with a few thin limestone beds.

Considering mineral composition, the sandstones present throughout the discussed succession belong to classes of quartz arenites, sub-lithic arenites and wackes (Folk 1980). Significant proportions of carbonate clasts appear only in the youngest part, i.e. the uppermost half of the sandstone-mudstone succession. The point-counting data plot on the Qm-F-Lt diagram (Fig. 7) within the quartzose and transitional fields of recycled orogen (Dickinson et al. 1983). Compositionally, points representing sandstones from each lithological subdivision plot within their own individual, however partly overlapping, area. In order to simplify the discussion of these results, the lithological subdivisions of the discussed succession are here numbered in the stratigraphically ascending order (Fig. 5): I - the sub-MTD deposits; II - the MTD complex; two parts of the sandstone-mudstone complex, namely: III - the lower part lacking carbonate grains, and IV - the upper part containing carbonate grains.

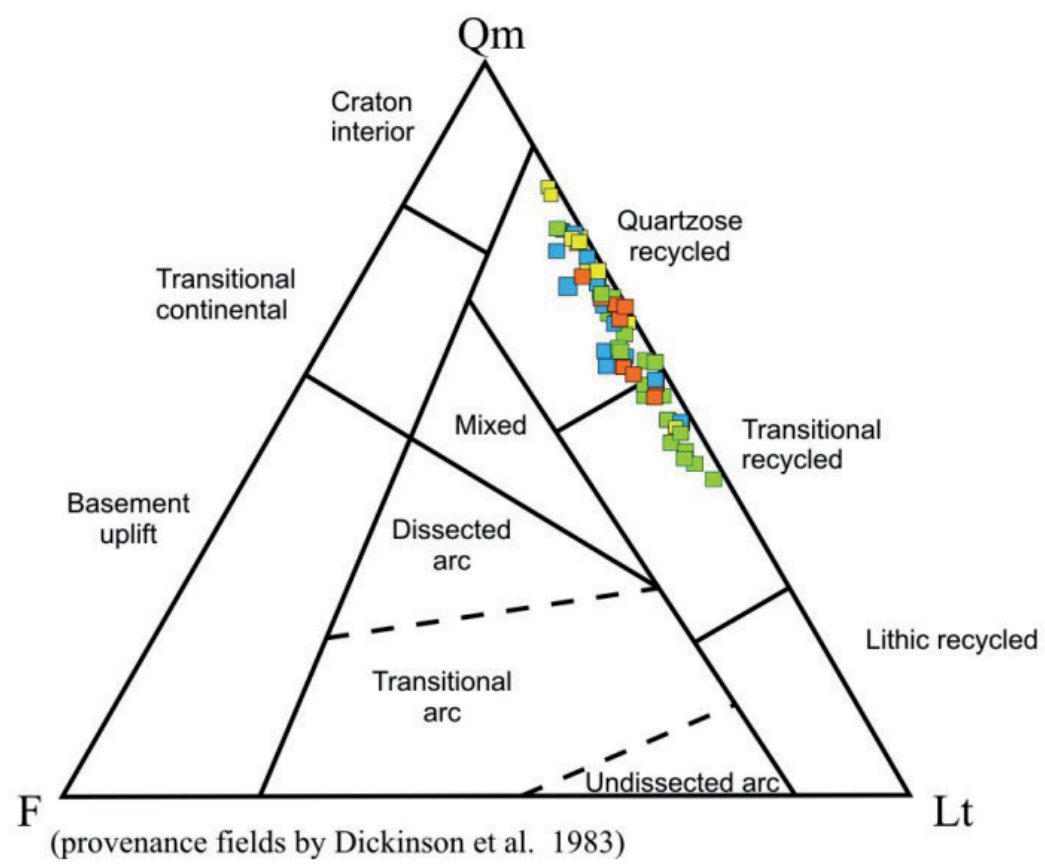

Fig. 7. Qm-F-Lt diagram documenting mineral composition and provenance of sandstones from three divisions of the Menilite Beds at Skrzydlna: I yellow - sub-MTD fine-grained division; II orange - MTD; sandstone-mudstone complex: III green - lower part lacking carbonate grains, and IV blue - upper part containing carbonate grains. Labels I-IV refer to the discussion in the text 
In spite of the fact that the plotted clusters overlap to a degree, it is possible to identify differences between them. Namely, the content of polycrystalline quartz and lithic grains of predominantly metamorphic rocks (gneisses, schists, quartzites) increases in the succession from I to III. This decrease in mineralogical maturity up the succession is considered to reflect unroofing related to the ongoing uplift of the source area and defined as normal unroofing sequence (Colombo 1994). Carbonate grains, so abundant in IV, are mostly represented by skeletal grains (up to $24 \%$ ) and occasionally sand-size carbonate rock fragments (less than 9\%). In general, their frequency increases in the stratigraphic succession of interval IV.

\section{INTERPRETATION AND DISCUSSION}

In the turn of Eocene and Oligocene, in the northern part of the Carpathian accretionary wedge there was the Menilite-Krosno Basin subdivided into two depositories by an emergent elevation of the Silesian Ridge; these were the Dukla - Fore-Magura Basin in the south and the Silesian Basin in the north. The southern margin of the Dukla Basin was marked by an elevation of the Fore-Magura Ridge beyond which a broad Magura basin extended to the south. Deposition in the Menilite-Krosno Basin was at that time dominated by the Menilite Beds - a facies association typified by organic-rich shales (Ślączka 1971, Cieszkowski et al. 2009, Golonka et al. 2013).

The menilite shales outcropping at Skrzydlna were deposited in low energy, deep, calm basin interrupted by one stage of influx of rapidly decelerating, high-density, sandy turbidity currents and recorded by an interlayer of massive amalgamated sandstone beds. Low-energy sedimentation of the pelitic limestone beds deposited as pelagic strata was interrupted at intervals by traction currents transporting small quantities of terrigenous sand, which formed solitary/starved current ripplemarks and very thin sandy laminae. The sandstone dykes injected into the menilite shales and the overlying limestones are interpreted here as resulting from liquefaction of the underlying sandstone beds (Dżułyński \& Radomski 1957). It is suggested that a sudden influx of quickly decelerating erosive turbidites and injection of fluidised sand may be considered as the earliest indication of uplift, and seismic events, related to the initial growth of the structure, which was to become the emergent source area that later on shed the MTD sediments.

The rapid uplift of the source area is indicated by extreme facies contrasts between the finegrained deposits of the sub-MDT strata and the overlying MTD complex constituted by the association of facies, which are genetically interpreted as follows: Clast-supported conglomerates of facies A, characterized primarily by extremely coarse clast sizes, massive beds up to $4 \mathrm{~m}$ thick, sandy matrix, chaotic structure and erosional lower boundaries are interpreted as deposits of non-cohesive debris flows (Lucente \& Pini 2008). Two subfacies of matrix-supported conglomerates are considered here as: (i) deposits of sandy debris flows in case of very coarse grained massive conglomerates (subfacies B1 Lucente \& Pini 2008), and (ii) high density turbidites represented by finer-grained, sandy, often normally-graded conglomerates with clasts aligned parallel to bed boundaries (Lowe 1982, Shanmugam 1996, Talling et al. 2012). Partition of C-facies beds into two parts of clearly different grain-size (conglomerate and sandstone) can be interpreted as result of deposition from bipartite sediment gravity flows, i.e. initial gravelly debris-flow evolving into high-density sandy turbidity current (Sohn 1999). Massive structure and mudstone rip-up clasts characteristic for Facies D suggest high erosional power and deposition by high-density, quickly decelerating turbidity currents. Normal grading passing into ripple-cross lamination intervals towards the bed tops imply transitions to low-density turbidites at the final stage of deposition out of individual flows (Talling et al. 2012). Mudstone beds (Facies E) represent rare breaks in deposition of the coarse-clastic MTD intervals. Sandy admixture in lower parts of some normally-graded mudstone beds suggests deposition out of strongly diluted turbidity currents 
(Bouma 1962). Massive, pure mudstone beds suggest hemipelagic deposition. Normal grading of sandstone interval in the lower part of Facies $\mathrm{F}$ beds (sandstone grading to mudstone) suggests deposition from high-density turbidity currents, whereas the overlying parallel-laminated interval enriched in coalified plant detritus implies transition to low density turbidite (Ghibaudo 1992). The whole bed of such facies represents incomplete Bouma sequence Tabe. Sedimentary breccia (Facies G) is interpreted as a small lens of slumped layer of only partly lithified sandstone and mudstone.

The common presence of black shale intraclasts in the conglomerate beds suggests erosion of the proximal part of the basin plain paved with the dark-coloured sediments, which was uplifted and thus transformed into slope adjacent to the elevated source. The lower part of the sandstone-mudstone complex is dominated by products of quickly depositing sandy debris flows and high-density turbidites (Talling et al. 2012). These evolve into deposits of low density turbidites in the upper part of the succession.

Considering the association of facies, indicators of intense erosion synchronous with origin of the MTD complex, deposition within a submarine canyon eroded in response to rapid uplift and emergence of the source zone may be suggested. The sequence of MTD evolving upwards into F-U sandstone-mudstone suite records facies retrogradation, which documents decreasing rates of supply and dynamics of the sediment distribution system.

The increasing proportion of polycrystalline quartz and lithic grains of predominantly metamorphic rocks up the succession of intervals I-III documents a decrease in the mineralogical maturity interpreted as normal unroofing sequence (Colombo 1994), which reflects progressive uplift of the source area. The appearance of the carbonate grains - products of a "carbonate factory" at the source - in the upper part of the sandstone-mudstone complex (interval IV) is considered to reflect transition of the provenance area from siliciclastic to mixed siliciclastic-calcareous.
A general increase of carbonate grains frequency up the interval IV suggests tectonic quiescence that followed vigorous uplift and resulted in a decrease in supply of terrigenous detritus.

\section{CONCLUSIONS}

The heterogeneous succession outcropping at Skrzydlna Quarry reflects significant variations in sedimentation modes, controlled by rapid modifications of the sediment supply and distribution system caused by tectonic uplift of a newly formed source area and transformation of a part of the Dukla basin floor into slope.

Sandstone dykes and amalgamated sandstones in the lowermost part of the succession, which originated within the basal, predominantly very fine-grained sedimentary unit deposited in a relatively stable anoxic basin, can be considered as the earliest indicators of the approaching uplift of the basin floor and emergence of a local source zone.

Rapid uplift and emergence of a new source area are reflected by the MTD complex that consist mainly of extremely coarse-grained deposits emplaced mostly by non-cohesive debris flows and high-density turbidity currents_which were deposited proximally to the emergent source area.

The F-U sandstone-mudstone complex, which succeeds the MTD, resulted predominantly from turbidity currents of high- and low-density; its F-U sequence records facies retrogradation and reflects decreasing rates of supply and dynamics of the sediment distribution system.

Uplift and erosion of the source zone, i.e. normal unroofing succession, is indicated by increasing content of polycrystalline quartz and lithic grains, derived mainly from metamorphic rocks, with simultaneous decrease in monocrystalline quartz up the succession.

Rapid tectonic uplift responsible for deposition of the MTD complex was followed by tectonic quiescence documented by the appearance and gradual increase of admixture of carbonate detritus in sandstones in the uppermost part of the succession. 
The authors are grateful to the reviewers Krzysztof Bąk and Diana Dirnerová - for thorough revisions and suggestions that enabled to improve the paper considerably. The Management of the "Mining Company Skrzydlna" is thanked for allowing us access to outcrops located in the mining license area. This research was financially supported by the AGH University of Science and Technology grant No.15.11.140.638 as well as Statutory Research No. 11.11.140.626 and 11.11.140.005, and a part of the research was carried out within the framework of the NCBiR BLUEGAS II ShaleCarp/14 project.

\section{REFERENCES}

Bouma A.H., 1962. Sedimentology of some Flysch Deposits: A Graphic Approach to Facies Interpretation. Elsevier, Ansterdam, 168.

Burtan J., 1974. Szczegółowa mapa geologiczna Polski 1 : 50,000. Ark. Mszana Dolna. Wydawnictwa Geologiczne, Warszawa.

Burtan J., 1978. Objaśnienia do Szczegółowej mapy geologicznej Polski 1 : 50,000. Ark. Mszana Dolna. Wydawnictwa Geologiczne, Warszawa.

Cieszkowski M., 1992. Strefa Michalczowej - nowa jednostka strefy przedmagurskiej w Zachodnich Karpatach fliszowych i jej geologiczne otoczenie. Geologia - Akademia Górniczo-Hutnicza im Stanisława Staszica w Krakowie, 18, 1-125.

Cieszkowski M., Golonka J., Krobicki M., Ślączka A., Oszczypko N., Waśkowska-Oliwa A. \& Wendorff M., 2009. The Northern Carpathians plate tectonic evolutionary stages and origin of olistolites and olistostromes. Geodinamica Acta, 22, 1-3, 101-126.

Cieszkowski M., Golonka J., Ślączka A. \& Waśkowska A., 2012. Role of the olistostromes and olistoliths in tectonostratigraphic evolution of the Silesian Basin in the Outer West Carpathians. Tectonophysics, 568, 248-265.

Colombo F., 1994. Normal and reverse unroofing sequences in syntectonic conglomerates as evidence of progressive basinward deformation. Geology, 22, 235-238.

Dickinson W.R., Beard L.S., Brakenridge G.R., Erjavec J.L., Ferguson R.C., Inman K.F., Knepp R.A., Lindberg F.A. \& Ryberg P.T., 1983. Provenance of North American Phanerozoic sandstones in relation to tectonic setting. Geological Society of America Bulletin, 94, 2, 222-235.

Dziadzio P., Borys Z., Kuk S., Masłowski E., Probulski J., Pietrusiak M., Górka A., Moryc J., Baszkiewicz A., Karnkowski P., Karnkowski P. \& Pietrusiak M., 2006. Hydrocarbon resources of the Polish Outer Carpathians - reservoir parameters, trap types, and selected hydrocarbon fields: a stratigraphic review. [in:] Golonka J. \& Picha F. (eds.), The Carpathians and their foreland: geology and hydrocarbon resources, AAPG Memoir, 84, American Association of Petroleum Geologist, Tulsa, 259-291.
Dżułyński S. \& Radomski A., 1957. Zagadnienie żył klastycznych $\mathrm{w}$ osadach fliszowych na tle sedymentacji fliszu karpackiego (Clastic dykes in the Carpathian Flysch). Rocznik Polskiego Towarzystwa Geologicznego, 26, 3, 225-264.

Folk R.L., 1980. Petrology of sedimentary rocks. Hemphill Publishing Company.

Ghibaudo G., 1992. Subaqueous sediment gravity flow deposits: practical criteria for their field description and classification. Sedimentology, 39, 3, 423-454.

Golonka J., Pietsch K. \& Marzec P., 2011. Structure and plate tectonic evolution of the northern Outer Carpathians. [in:] Closson D. (ed.), Tectonics, InTech, Rijeka, 65-92.

Golonka J., Ślączka A., Waśkowska A., Krobicki M. \& Cieszkowski M., 2013. Budowa geologiczna zachodniej części polskich Karpat zewnętrznych. [in:] Krobicki M. \& Feldman-Olszewska A. (red.), Głębokomorska sedymentacja fliszowa: sedymentologiczne aspekty historii basenów karpackich: V Polska Konferencja Sedymentologiczna POKOS 5'2013: 16-19.05.2013, Żywiec: abstrakty referatów i posterów oraz artykuły: przewodnik do wycieczek, Państwowy Instytut Geologiczny - Państwowy Instytut Badawczy, Warszawa, 11-62.

Haczewski G., 1989. Poziomy wapieni kokkolitowych w serii menilitowo-krośnieńskiej - rozróżnianie, korelacja i geneza. Annales Societatis Geologorum Poloniae, 59, 3-4 435-523.

Jankowski L., Margielewski W. \& Urban J., 2012. Strukturalne i litofacjalne uwarunkowania rozwoju rzeźby polskich Karpat zewnętrznych. [in:] Strukturalne i litofacjalne uwarunkowania rozwoju rzeźby polskich Karpat zewnętrznych: III Warsztaty Geomorfologii Strukturalnej: Beskid Niski, Beskid Sąecki, Babia Góra, Dukla, Piwniczna, Zawoja, 25-28 września 2012 r., Instytut Ochrony Przyrody. Polska Akademia Nauk, Kraków, 25-28.

Jucha S. \& Kotlarczyk J, 1961. Seria menilitowo-krośnieńska w Karpatach fliszowych. Prace Geologiczne, 4, Wydawnictwa Geologiczne, Warszawa.

Jugowiec-Nazarkiewicz M., 2007. Nanoplankton wapienny górnokredowych facji pelagicznych jednostki podśląskiej polskich Karpat fliszowych. Biuletyn Państwowego Instytutu Geologicznego, 426, 53-70.

Karnkowski P., 1999. Oil and gas deposits in Poland. Geosynoptics Society GEOS, Kraków.

Konon A., 1997. Tektonika masywu Śnieżnicy (Beskid Wyspowy, Płaszczowina Magurska). Przegląd Geologiczny, 45, 1001-1007.

Koszarski L., Sikora W. \& Wdowiarz S., 1974. The Flysh Carpathians. Polish Carpathians. [in:] Mahel M. (ed.), Tectonics of the Carpathian-Balkan Regions. Explanations to the Tectonic Map of the Carpathian-Balkan Regions and their Foreland, Štátny geologický ústav Dionýza Štúra, Bratislava, 180-197.

Kotarba M.J., Więcław D., Bilkiewicz E., Dziadzio P. \& Kowalski A., 2017. Genetic correlation of source rocks and natural gas in the Polish Outer Carpathians and Paleozoic-Mesozoic basement east of Kraków (southern Poland). Geological Quarterly, 61, 4, 795-824.

Kotlarczyk J., Jerzmańska A., Świdnicka E. \& Wiszniowska T., 2006. A framework of ichthyofaunal ecostratigraphy of 
the Oligocene-Early Miocene strata of the Polish Outer Carpathian Basin. Annales Societatis Geologorum Poloniae, 76, 1, 1-111.

Książkiewicz M., 1977. The tectonics of the Carpathians. [in:] Pożaryski W. (ed.), Geology of Poland. Vol. 4: Tectonics, Wydawnictwa Geologiczne, Warszawa, 476-618.

Kuśmierek J., 1990. Zarys geodynamiki centralnokarpackiego basenu naftowego. Prace Geologiczne - Polska Akademia Nauk. Oddział w Krakowie. Komisja Nauk Geologicznych, 135, Zakład Narodowy im. Ossolińskich, Wrocław [etc.].

Leszczyński S., Warchoł M. \& Starzec K., 2008. Zapis ewolucji Karpat polskich w osadach eocenu górnego-oligocenu dolnego.[in:] Haczewski G. (red.), Pierwszy Polski Kongres Geologiczny, Kraków, 26-28 czerwca 2008: przewodnik sesji terenowych, Polskie Towarzystwo Geologiczne, Kraków, 47-77.

Lowe D.R., 1982. Sediment gravity flows: II. Depositional models with special reference to the deposits of high-density turbidity currents. Journal of Sedimentary Petrology, 52, 279-297.

Lucente C.C. \& Pini G.A., 2008. Basin-wide mass-wasting complexes as markers of the Oligo-Miocene foredeep-accretionary wedge evolution in the Northern Apennines, Italy. Basin Research, 20, 1, 49-71.

Olszewska B., 1985. Otwornice warstw menilitowych polskich Karpat zewnętrznych. Annales Societatis Geologorum Poloniae, 55, 201-250.

Oszczypko-Clowes M. \& Ślączka A., 2006. Nannofossils biostratigraphy of the Oligocene deposits in the Grybów tectonic window (Grybów Unit, Western Carpatians, Poland). Geologica Carpathica, 57, 473-482.

Oszczypko N., 2006. Late Jurassic-Miocene evolution of the Outer Carpathian fold-and-thrust belt and its foredeep basin (Western Carpathians, Poland). Geological Quarterly, 50, 1, 169-194.

Polak A., 1999. Budowa geologiczna płaszczowiny śląskiej w okolicy Skrzydlnej. Przegląd Geologiczny, 47, 8, 753-763.

Polak A., 2000. Poziom gruboziarnistych zlepieńców w okolicy Skrzydlnej (Beskid Wyspowy). Przegląd Geologicz$n y, 48,7,644-650$.

Pszonka J., 2015. Studium sedymentologiczne warstw cergowskich $w$ jednostce dukielskiej i przeddukielskiej Karpat fliszowych [Sedimentological study of the Cergowa Beds in the Dukla and Fore-Dukla Units of the Flysch Carpathians]. Studia, Rozprawy, Monografie, 196, IGSMiE PAN, Kraków.

Pszonka J. \& Wendorff M., 2017. Carbonate cements and grains in submarine fan sandstones, the Cergowa Beds (Oligocene, Carpathians of Poland) recorded by cathodoluminescence. International Journal of Earth Sciences, 106, 1, 269-282.

Puglisi D., Badescu D., Carbone S., Corso S., Franchi R., Giglioto L.G., Loiacono F., Miclaus C. \& Moretti E., 2006. Stratigraphy, petrography and palaeogeographic significance of the Early Oligocene "menilite facies" of the Tarcau Nappe (Eastern Carpathians, Romania). Acta Geologica Polonica, 56, 1, 105-120.

Selley R.C. \& Sonnenberg S.A., 2015. Elements of Petroleum Geology. $3^{\text {rd }}$ ed. Elsevier, Amsterdam.
Shanmugam G., 1996. High-density turbidity currents; are they sandy debris flows? Journal of Sedimentary Research, 66, 1, 2-10.

Siemińska A., Starzec K. \& Wendorff M., 2017a. Skrzydlna quarry (Oligocene Menilite Formation). Field Trip Stop 13. [in:] Krobicki M. (ed.), $6^{\text {th }}$ International symposium of the international geoscience programme (IGCP) project-589: development of the Asian Tethyan Realm: genesis, process and outcomes: Western Tethys meets Eastern Tethys: Kraków (Poland), 29 September-5 October 2017: abstract volume \& field trip guidebook, Polish Geological Institute - National Research Institute, Warsaw, 138-142.

Siemińska A., Wendorff M. \& Žecova K., 2017b. Sedimentary features and nannostratigraphy of olistostrome bearing sequence at Skrzydlna quarry (Oligocene) - preliminary results. [in:] Krobicki M. (ed.), $6^{\text {th }}$ International symposium of the international geoscience programme (IGCP) project-589: development of the Asian Tethyan Realm: genesis, process and outcomes: Western Tethys meets Eastern Tethys: Kraków (Poland), 29 September-5 October 2017: abstract volume \& field trip guidebook, Polish Geological Institute - National Research Institute, Warsaw, 40-41.

Sikora W., 1970. Budowa geologiczna płaszczowiny magurskiej między Szymbarkiem Ruskim a Nawojową. Biuletyn Instytutu Geologicznego, 235, 13, 5-121.

Sohn Y.K., 1999. Rapid development of gravelly high-density turbidity currents in marine Gilbert-type fan deltas, Loreto Basin, Baja California Sur, Mexico. Sedimentology, 46, 4, 757-761.

Soták J., 2010. Paleoenvironmental changes across the Eocene-Oligocene boundary: insights from the Central-Carpathian Paleogene Basin. Geologica Carpathica, $61,5,393-418$.

Švábenická L., Bubík M. \& Stránik Z., 2007. Biostratigraphy and paleoenvironmental changes on the transition from Menilite to Krosno litofacies (Western Carpathians, Czech Republic). Geologica Carpathica, 58, 3, 237-262.

Ślączka A., 1971. Geologia jednostki dukielskiej [The geology of the Dukla Unit, Polish Flysch Carpathians]. Prace Instytut Geologiczny, 63, Wydawnictwa Geologiczne, Warszawa.

Ślączka A. \& Kamiński M., 1998. A guidebook to excursions in the Polish Flysch Carpathians. Grzybowski Foundation Special Publication, 6, Grzybowski Foundation.

Ślączka A., Krugłow S., Golonka J., Oszczypko N. \& Popadyuk I., 2006. Geology and hydrocarbon resources of the Outer Carpathians, Poland, Slovakia, and Ukraine: general geology. [in:] Golonka J. \& Picha F. (eds.), The Carpathians and their foreland: geology and hydrocarbon resources, AAPG Memoir, 84, American Association of Petroleum Geologists, Tulsa, 221-258.

Ślączka A. \& Unrug R., 1976. Trends of textural and structural variation in turbidite sandstones: the Cergowa Sandstone (Oligocene, Outer Carpathians). Rocznik Polskiego Towarzystwa Geologicznego, 46, 55-76.

Talling P.J., Masson D.G., Sumner E.J. \& Malgesini G., 2012. Subaqueous sediment density flows: Depositional processes and deposIt types. Sedimentology, 59, 1937-2003. 
Wendorff M., Siemińska A., Moszkowicz A. \& Godlewski P., 2015. Facies variations and depositional modes in an olistostrome sequence grading to turbidite fan succession within the Menilite Beds (Oligocene) at Skrzydlna, Polish Outer Carpathians. [in:] 31 $1^{\text {st }}$ IAS meeting of sedimentology: Kraków 22 ${ }^{\text {nd }}-25^{\text {th }}$ June, 2015: abstracts, Polish Geological Society, Kraków, 579 [electronic document].
Zytko K., Zając R., GucikS., Ryłko W., Oszczypko N., Garlicka I., Nemčok J., Eliáš M., Menčik E., Stránik Z., Rakus M. \& Matejovska O., 1989. Geological map of the Western Outer Carpathians and their foreland without Quaternary formations, 1:500,000. [in:] Poprawa D. \& Nemčok J. (eds.), Geological Atlas of the Western Outer Carpathians and Their Foreland, Państwowy Instytut Geologiczny, Warszawa. 